\section{Ved udgivelsen af Werner Bests korrespondance}

\author{
Det Kongelige Bibliotek 25.9.2012
}

af professor, dr.phil. Per Øhrgaard, Carlsbergfondet

$\mathrm{M}$ ine damer og herrer! Dette er jo en slags festtale om dr. Best. Fest og Best lyder som et dårligt rim, men i det hele taget kunne den rigsbefuldmægtigedes navn bruges til så meget. "Hvem er de tre betydeligste tyskere?" spurgte man, og svaret lød: "Det er Best Hitler Himmler.” Det gjorde så Hitler, men det drømte Best ikke om. Efter afsoning af ca. halvdelen af sin endelige straf (hvis man regner varetægten med) blev han udvist af Danmark og blev en slags grå eminence i det Frie Demokratiske Parti i Nordrhein-Westfalen, som i det hele taget var noget af et opsamlingssted for gamle nazister.

Men for et øjeblik endnu at blive i det anekdotiske og i det dårlige rim: Man kunne forveksle Best og Fest. I sommeren 1943 fik den tyske forfatter Hans Henny Jahnn, som boede på Bornholm, men ikke var i egentligt eksil og fremdeles tysk statsborger, besked på at forlade øen, som var erklæret for "Sicherheitsgebiet" (se bind 3 s. 237, dok. 151), hvad der betød, at ingen voksne civile tyskere måtte opholde sig på øen. Jahnn rendte de tyske myndigheder i København på dørene, og de blev åbenbart så trætte af ham, at han efter nogen tid fik lov at vende tilbage. I 1945 fik Jahnn så - i lighed med alle andre tyskere og japanere
- sin ejendom (i hans tilfælde salgssummen for den gård, han havde boet på og solgt i foråret 1945) konfiskeret, og under hans bestræbelser på at få denne afgørelse omstødt foreholdt man ham, at det var dr. Best, der havde givet ham tilladelse til at vende tilbage til Bornholm. Det måtte jo betyde, at Jahnn havde stået sig godt med Best - hvilket Jahnn bestred: Han havde aldrig mødt Best og var i øvrigt antinazist (hvad der var rigtigt nok og selv i sommeren $1945 \mathrm{blev}$ bekræftet af hans bornholmske naboer). Under arkivstudier fandt jeg engang tilladelsen til Jahnn, og den var underskrevet af Legationsrat A. Fest - heraf hele balladen. Nu ved jeg så også, hvad A. står for, nemlig Anton, for han optræder en enkelt gang i det nu udgivne storværk og kan derfor findes i dets formidable register i bind 10, som med sine oversigter, tabeller og altså registre i det hele taget er en guldgrube for enhver, der søger specifikke oplysninger; og det er jo mest dem, man vil søge i et værk som dette.

Men hele værket er en guldgrube, som jeg naturligvis kun er begyndt at skrabe lidt i overfladen af. Der er formentlig heller ingen, der ville tro mig, hvis jeg sagde, at jeg i de forløbne par uger havde læst alt. En fortræffelig vejledning giver de danske oversigter forud for hvert dokument, mine stikprøver har i hvert fald ikke vist overspringelser eller misforståelser. $\mathrm{Og}$ forkortelseslisten i bind 10 er en nødvendig gave selv til den, der er halvvejs fortrolig med de forskellige tjenester og deres grader.

Da Werner Best kom til Danmark, var krigslykken ved at vende, og den intelligente Best kan meget vel have været en af dem, der havde indset, hvad historikere siden har peget på, nemlig at krigen på 


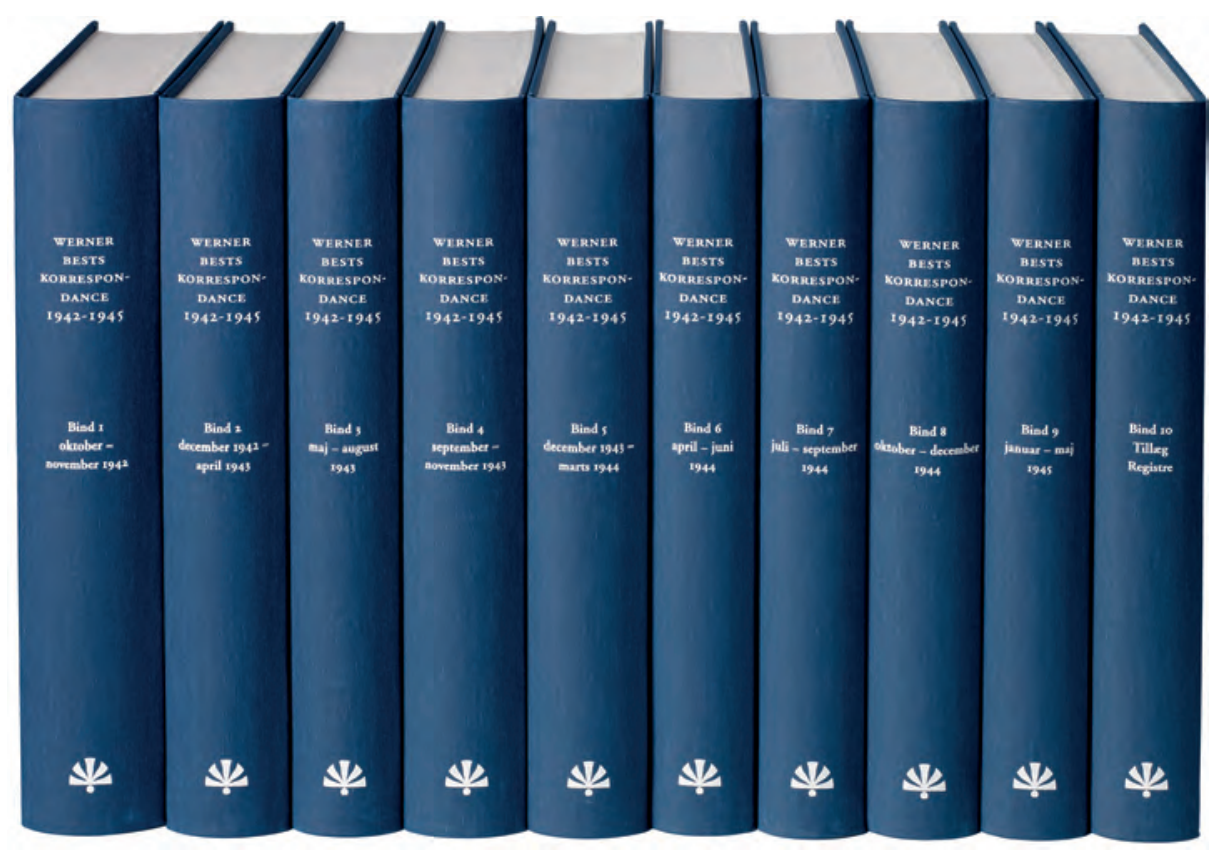

Werner Bests korrespondance med Auswärtiges Amt og andre tyske akter vedrørende besættelsen af Danmark 1942-1945. Udgivet af John T. Lauridsen under medvirken af Jakob K. Meile. Det Kongelige Bibliotek \& Selskabet for Udgivelse af Kilder til dansk Historie, 2012.

en måde var tabt for Tyskland allerede i slutningen af 1941 , da det ikke var lykkedes at indtage Moskva, og da USA var trådt ind i krigen - absurd nok efter en tysk krigserklæring.

Bests optræden i Danmark kunne således godt - allerede før hans ageren i forbindelse med jødeaktionen i oktober 1943 - tolkes også som en slags livsforsikring. Werner Best var ellers ikke hjemmefra manden, der tog hensyn til ret meget; han var nazist helt igennem og medforfatter til de såkaldte Boxheimer Dokumente fra 1931, som mere end antydede, hvorledes nazisterne ville gå frem efter en voldelig magtovertagelse (og som vakte Hitlers mishag, fordi han ville til magten på legal vis). Best havde optrådt i Polen og i Frankrig, før han kom til Danmark, og i det omfang, man her i landet kunne vide noget om denne fortid, var der ingen grund til at forvente sig noget godt af hans udnævnelse.

Det er til gengæld svært at nægte, at Bests embedsførelse hele vejen igennem sigtede mod at få tingene til at glide, og det forekommer også, at danskerne, herunder den gryende modstandsbevægelse, måske ikke var hans største problem; det var derimod de interne tyske kompetencestridigheder affødt af, at besættelsen af Danmark havde en anden karakter end alle de andre tyske besættelser. Meget af Bests politik handlede om at bevare et spillerum over for andre instanser, så det var naturligvis ikke for danskernes blå øjnes skyld, at han manøvrerede, som han gjorde. 
Men ønsket om at få tingene til at glide delte han med den mand, som havde været dansk udenrigsminister i de foregående par år, og som blev statsminister netop i tiden omkring Bests ankomst, der igen var udløst af den såkaldte telegramkrise i efteråret 1942: Erik Scavenius. Hans Kirchhoff og måske andre har ved et par lejligheder antydet, at der etableredes en slags far-søn-relation mellem Scavenius og Best, og det anser jeg for meget sandsynligt. Scavenius - som ikke efterlod sig noget privatarkiv - var født samme år som Werner Bests far, der var faldet i Første Verdenskrig, altså i sønnens teenageår, så Best havde ingen far, og Scavenius havde ingen børn. De kan meget vel have fundet hinanden også på det plan; i hvert fald udvikledes der en relation mellem dem, som synes at være gået ud over det rent forretningsmæssige, og som derfor også fortsatte efter krigen.

$\mathrm{Nu}$ til dags ved man en del om deres korrespondance, om Scavenius' idé om, at Best skulle skrive sin version af besættelsestiden, som Scavenius havde skrevet sin, om Bests ønske om et forord fra Scavenius osv. I samtiden fik offentligheden selvsagt ikke indblik i det, men i private sammenhænge lagde Scavenius ikke skjul på forbindelsen, som det fremgår af professor Carl Roos' dagbog, hvor han refererer fra en samtale med Scavenius i april 1953: "Stod i forb. med Best, der havde sendt ham udkast t. et skrift. Raadede B. til at holde sig alene til det han havde oplevet personl. i Danm. Havde ført en "to-frontkrig"; den ene front var ordrerne fra Berlin, som han i udstrakt grad saboterede, hvilket var muligt da han havde indlagt sig store fortjenester af partiet. Tysk ordre var 5 dræbte for hver modstandsbevægelsen dræbte. Det skete ikke; der var begaaet flere mord af modstandsbevægelsen end af de tyske og deres hjælpere. [...] Tyskerne havde tilsidst indkredset "Frihedsraadet" og havde kunnet arrestere dem alle naarsomhelst, men hvorfor? De vilde blot faa besvær med nogle andre. (Det var deres ræsonnement)." (Roos' dagbog, 24.4.1953) Det lader vi stå ved sit værd; om Scavenius' vurdering er rigtig eller forkert, er i den forbindelse uden betydning.

Men hverken Scavenius eller Best ville formentlig have udviklet eventuelle venskabelige følelser (i det omfang, Scavenius overhovedet var venlig!), hvis de ikke havde haft en overordnet fælles interesse - som Scavenius for sit vedkommende kun kunne forfølge i den korteste del af Bests embedsperiode, nemlig indtil den 29. august 1943. Best holdt sig i samme spor også bagefter, dels fordi et roligt Danmark var hans magtbasis, dels - som antydet - måske også fordi han ikke kalkulerede med en tysk sejr. Han lå i stadig clinch med den øverstbefalende for de tyske tropper i Danmark, general von Hanneken, og siden også med den højere SS- og politifører Günther Pancke, "den højere Pancke", som han blev kaldt i folkemunde. Over for gentagne krav fra andre - og/eller fra Berlin - om at gå hårdere til værks over for modstandsbevægelsen og dens sabotage argumenterede Best hver gang med, at for megen uro i Danmark ville hæmme den danske produktion og levering af landbrugsvarer til Tyskland - et argument, som i betragtning af disse leverancers stadig større betydning ikke forfejlede sin virkning (se f.eks. Forstmanns indberetning, bd. 4, nr. 195). For at opretholde en tilstrækkelig dansk produktion måtte der også leveres råvarer og energi (kul) fra Tyskland, og i 
begyndelsen af november 1943 omdirigerer man endog et antal landbrugsmaskiner fra Generalgouvernementet i Polen til Danmark for at holde danskerne muntre (bd. 4, nr. 388). I øvrigt drejede det sig ikke alene om landbrugsvarer, men også om militært udstyr fra Industrisyndikatet. Man kan give det en tanke, at Bertolt Brecht i 1938 havde skrevet en enakter (Hvad koster Svinet?) om at danskerne først og fremmest tænkte økonomisk, og at en medarbejder i Auswärtiges Amt samtidig nåede til samme konklusion: Hvis man aftog danskernes varer, ville de nok skikke sig.

Jeg slog så ned et ikke helt tilfældigt sted, i oktober-november 1943, hvor jeg ville se, hvorledes aktionen mod de danske jøder blev rapporteret. For en gangs skyld havde Best og von Hanneken været enige: Det var en dårlig idé, som ville skade forholdet til Danmark og dermed også de danske leverancer til Tyskland, men samtidig forsøgte Hanneken at få aktionen udskudt til efter ophævelsen af den undtagelsestilstand, der var indført, så Best ville stå alene med ansvaret. I forvejen var situationen efter den 29. august problematisk: Tyskerne prøvede at få indsat en ny dansk regering (det var de forhandlinger, der endte med departementchefstyret), det danske militær skulle afvæbnes, og oveni kom en ordre fra Hitler om, at man skulle forsøge at hverve regulære danske soldater og sende ca. 4.000 af de yngste årgange, herunder rekrutter, til Tyskland. Heller ikke dette var hverken Best eller von Hanneken begejstret for, sidstnævnte tilslutter sig en SS-førers mening, nemlig at "selv efter en grundig skoling vil succesen, danskernes egenart taget i betragtning, være tvivlsom” (bd. 4, nr. 141).
Så meget havde de lugtet sig frem til - og i det hele taget var tyskerne jo ikke dumme. Som barn hørte jeg historier om, hvordan modstandsbevægelsen havde "narret" tyskerne ved forskellige lejligheder. Senere gik det op for mig, at tyskerne i de fleste situationer udmærket vidste, hvad der foregik, men ikke tillagde det voldsomt stor betydning. Det er tydeligt, at man ikke på noget tidspunkt før måske til allersidst frygter et dansk oprør, f.eks. noterer alle de tyske instanser i september 1943, at den undtagelsestilstand, der blev indført i slutningen af august, har reduceret sabotagen væsentligt. Den mere åbne modstand kan man altså godt holde nede, hvis man vil - nej, det der er grund til at frygte, er dansk passiv modstand, den danske egenart, guddommeligt illustreret af Bo Bojesen med den tegning, der hænger på udstillingen her udenfor: Et offentligt pissoir, hvor den ene væg optages af en tysk soldat i stiveste puds og med en lang række tomme båse ved siden af sig - og den anden væg, hvor trængende civile danskere klumper sig sammen for ikke at stå ved siden af tyskeren ...

Det mest frapperende ved Bests første telegram til Auswärtiges Amt 2. oktober 1943 om den veloverståede jødeaktion er - bortset fra sammenkædningen med løsladelsen af internerede danske soldater - at han overhovedet ikke fortæller, hvad der er foregået. I det næste telegram er der heller ingen konkrete oplysninger, derimod en understregning af, at der kan ventes større fødevareleverancer fra Danmark end hidtil antaget. Som en dårlig vittighed virker det, at det første signal til Berlin om, man ikke har pågrebet ret mange jøder, er et telegram fra Gestapo-chef Karl Heinz Hoffmann til Kiel, hvori han meddeler, at der slet ikke 


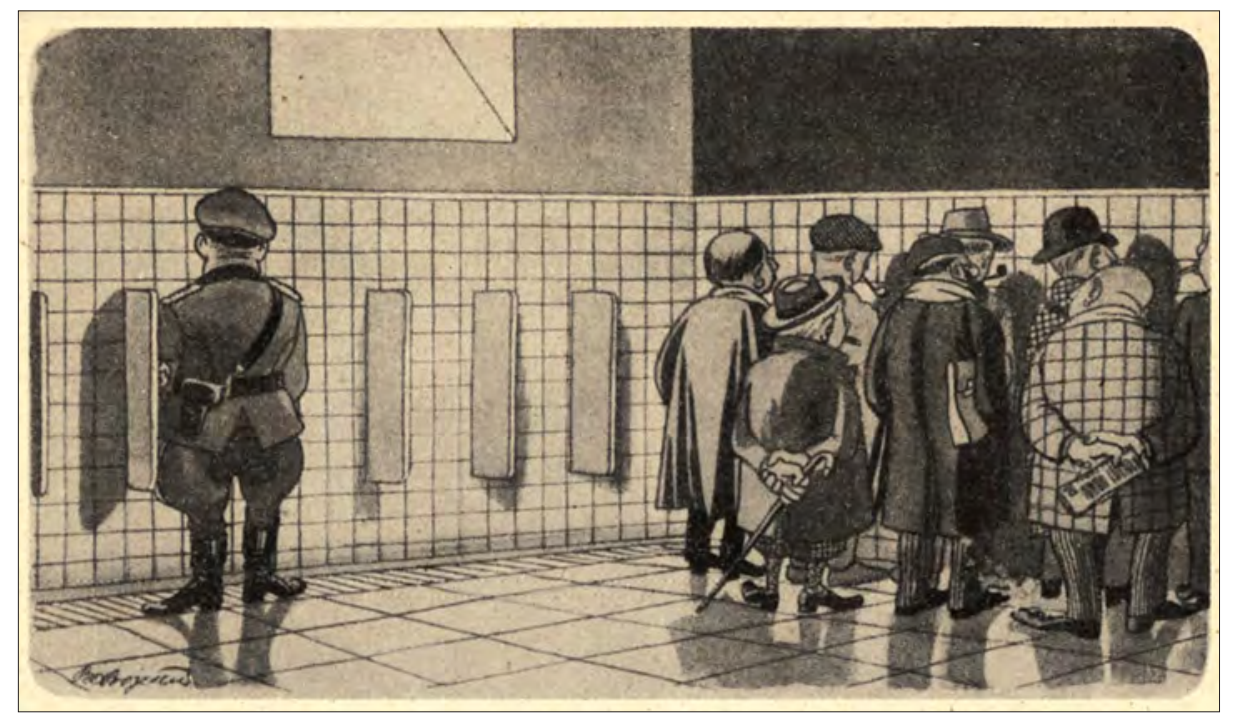

Bo Bojesen: Passiv modstand. Mandens Blad, juni 1945.

er jøder nok med toget fra Danmark til at retfærdiggøre at sende det direkte videre til Theresienstadt! - At søkrigsledelsen den 2. oktober noterer, at mange jøder er på vej til Sverige, vidner om, hvilket øje kikkerten blev sat for - det skulle vel netop have være Seekriegsleitungs opgave at forhindre denne flugt over Øresund. Og da Best endelig bekvemmer sig til at meddele lidt mere til Berlin i sit telegram af 5. oktober, undgår han endnu engang behændigt at give alle relevante oplysninger (bd. 4, nr. 242), men skriver rent ud, at man ikke kan forhindre nogen i at flygte over Øresund, hvis det er det, de vil. Den kluntede beslaglæggelse af Ollerup Gymnastikhøjskole (hvis forstander Niels Bukh jo ikke var ligefrem tyskfjendtlig) og danske skibes ureglementerede afsejling fra Spanien spiller en næsten lige så stor rolle som aktionen mod jøderne - eller skulle helst gøre det. Men jeg skal ikke forfølge den historie i detaljer, den er trods alt en af de i forvejen godt belyste.
Men der er også interessante bipersoner. Der er f.eks. professor Otto Höfler, som i marts 1943 leverer en afhandling om den åndelige situation i Skandinavien, i hvilken han prøver at forklare, hvorfor skandinaverne ikke rigtig synes at elske tyskerne (bd. 3, nr. 217). De er nemlig gennem Georg Brandes blevet inficeret af en jødisk skepticisme (og her er det sjovt at tænke på, at Brandes, da han boede $\mathrm{i}$ Berlin omkring 1880, angreb den danske skepticisme og beundrede, at man tog tingene mere alvorligt i Tyskland). Men skandinavernes inderste instinkt er ifølge Höfler alligevel "der Wille zum höheren Menschen”, hvad der står i nogen kontrast til det med landbrugseksporten. Som germanist har jeg haft fornøjelse af et par steder at støde på SS-Hauptsturmführer Hans Ernst Schneider fra Himmlers Ahnenerbe-institut. Det var nemlig ham, som efter krigen tog navneforandring til Schwerte, giftede sig igen med sin angivelige enke og gjorde en pæn karriere 
som professor i Aachen og forfatter til en estimeret studie i Goethes Faust, inden hans identitet blev afsløret kort før hans død (han døde i 1999, 90 år gammel, afsløringen kom i 1995). Som dansk germanist kan jeg så glæde mig over, at det er en stadig klage fra det tyske videnskabelige institut i København, at det er meget svært at få danske videnskabsmænd til at arbejde med på den europæiske nyordning. De kommer ikke til foredragene! (bd. 3, nr. 178).

Carlsbergfondet er glad og stolt over at have ydet sit bidrag til, at dette storværk har kunnet udgives. Og så slog jeg Carlsbergfondet op i registret og fandt dette: Den 27. september 1943 er der holdt et møde hos Best med deltagelse af den tyske kulturattaché og repræsentanter for Det preussiske Videnskabsakademi med henblik på at sikre, at dr.phil.habil. Wolja Erichsen, som er dansk, men boende i Berlin, hvor han nu er blevet udbombet, kan fortsætte sine videnskabelige arbejder og i den forbindelse rejse frem og tilbage mellem Danmark og Tyskland. Det refereres, at professor Johannes Pedersen som formand for Carlsbergfondet har tilsagt dettes støtte til dækning af dr. Erichsens ophold i Danmark. Det hele drejede sig om udarbejdelsen af en oldægyptisk (demotisk) ordbog, som havde været undervejs i et dansk-tysk samarbejde i mange år og fortsattes hen over Det tredje Rige og Anden Verdenskrig. I mødereferatet nævnes, at der har været "gelegentliche Anregungen" om at fratage Videnskabernes Selskab kontrollen med Carlsbergfondet og på en eller anden måde at statsliggøre dette; såfremt den rigsbefuldmægtigede skulle høre noget om det, må han endelig skride ind. "Beslutningsfriheden må med henblik på den videnskabelige autoritet forblive hos Videnskabernes Selskabs præsidium", siger lederen af Det preussiske Videnskabsakademi, og det kan man kun støtte ham i. Interessant i den forbindelse er det, at han bl.a. henviser til, at danske lærde efter Første Verdenskrig var blandt dem, som arbejdede stærkest for at re-integrere tyskere i det internationale videnskabelige samarbejde. (bd. 4, nr. 178). Der synes at være en anelse af betaling af taknemmelighedsgæld i holdningen.

Man kan for at vende tilbage til begyndelsens ordspil vel ikke ligefrem konkludere, at Best var det bedste, der kunne ske for Danmark; men der er næppe tvivl om, at det kunne have været adskilligt værre. Ingen anden tysk okkupation forløb så gelinde som vores. Eftersom det ikke skete for vores skyld, er der ingen grund til at være tyskerne i almindelighed eller dr. Best i særdeleshed taknemmelig. Men kendsgerningen er værd at notere det er den blevet tidligere, og nu kan den bekræftes. Til lykke til John T. Lauridsen, Jakob K. Meile og alle andre medvirkende, til Det Kongelige Bibliotek og til Selskabet for Udgivelse af Kilder til dansk Historie; men det kan tale for sig selv. 